\title{
昼光と日射の測定機器
}

\section{三宅 行美*}

\section{1.まえがき}

昼光と日射を総称した自然光を全天候下で連続的にかつ 精度よく計測することは大変むつかしいてとである．簡単 飞言らと, 昼光の計測は可視部の自然光を比視感度曲線に 合せて照度および輝度として計測するてとを意味し，日射 は波長域 $0.3 \sim 3.0 \mu \mathrm{m}$ の全放射量を計測するてとを意味 する. 従って, 両者の違いは測定対象は同じで単に分光特 性が異るだけである。しかしながら，両者の計測技術の歷 史は全く別々の過程を辿り今日に至っている.その結果と して, 現在は機器の原理, 性能の評価法やその表示方法も 大変違ったものとなっている.一つの理由は照度, 輝度の 計測は人工照明の計測が実用的にも重要視されたため自然 光の計測技術が十分とり入れられていないからではないか と考えられる.よって，今回の国際㡺光測定年に使用され る機器につらては, 全く異った発展をした両者の計測技術 を一つのシステムの中同じレベルの精度で取入れる必要 があった．規格を例にとってみてもWMO（世界気象機 構)，ISO と CIE の 3 つの勧告と規格があり，てれ等を整 合して測定機器の中に組入れて行く必要があった.

以上の背景より, 昼光と日射の計測機器の共通点とその 違いを, 構造, 性能, 校正方法等の項目について説明した n.

\section{2. 構 造}

測定対象である自然光の特長は経時的にその分光分布と 空間分布がランダムに変化することである．従っててれを 計測する機器はてれに十分対応でをるものでなければなら なら．特に後者の空間分布の変化に対応でをる計測機器の 特長は, 他の光量測定機器にあまり例をみないもので，て の計測精度に非常に大き影響を与える.次に環境温度の 変化として $50^{\circ} \mathrm{C}$ を考虑に入れ，その他の気像条件として， 風，雪等の条件があり全天候下での連続計測に十分耐える 堅牢さが要求される. さらに一般的な計測器に要求される

\footnotetext{
† Requirement of instrument for the measurement of daylight and solar radiation

*英弘精機株式会社 Yukiharu Miyake
}

紹介者 専門会員 中村 洋
直線性, 感度の経時变化, 零点の安定性等の各性能が兼ね そなわっていなければならない。

以上与えられた条件に対する昼光と日射計測のセンサの 部分の基本的な構造を図 1 (A)，(B) K示す. 図 1 (A)は照度を 計測する場合の例であり，均一な厚さのガラスドームによ り覆われている．とのドームはちうう，霜，雨等からその下 飞備えられた受光面である拡散板を保護する．との拡散板 により $\cos$ 特性（斜入射角特性）を満足させる構造となっ ている．昼光を照度として計測する場合と日射計測の場合 最も重要視されるのが $\cos$ 特性であり，0〜 $90^{\circ} \mathrm{C}$ の入射角 飞対し入射角の $\cos$ 飞比例した出力が取出世なければなら ない. 次に, 比視感度曲線にマッチさせるためのフィルタ 群が備えられる. 光電素子としては通常経時変化が少な く, かつ電気信号への変換効率の高い量子型の $\mathrm{Si}$ ダイオ ードが採用される.

図 1 (B)飞示される日射計測の場合は $\mathrm{Si}$ ダイオードが分 光特性として赤外部に感度がないてとと可視部でも感度が 均一でないてとから，変換効率は低いが日射の全波長域 $0.3 \sim 3.0 \mu \mathrm{m}$ 間で均一の分光感度を有し，汃安定性のあ る熱電堆がセンサとして使われる。この熱型センサは 3.0 $\mu \mathrm{m}$ 以上の赤外放射（夜間輻射）も一緒に検知するので 3. $0 \mu \mathrm{m}$ 以上の放射を完全にカットするガラスドームが不 可欠となる. またガラスドーム自体からの 2 次的な放射も カットするためもら一つのガラスドームが備えられる．言 いかえると現実的には赤外放射や風の影響による出力の零

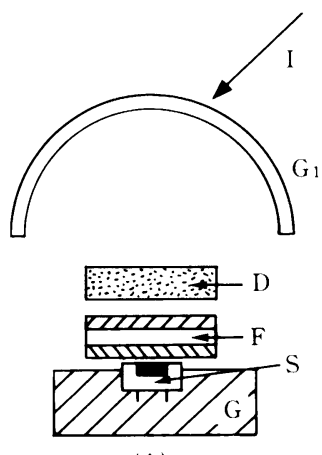

(A)

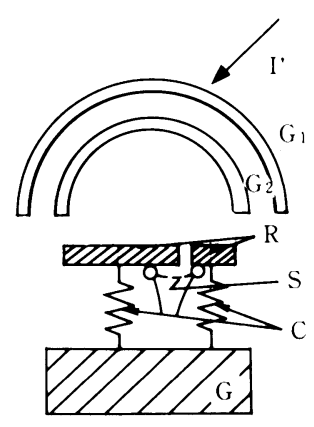

(B)

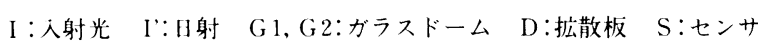
$\mathrm{G}$ :基 板 $\mathrm{R}$ :受光面 $\mathrm{C}$ :熱コンダクタンス $\mathrm{F}$ :フィルタ 


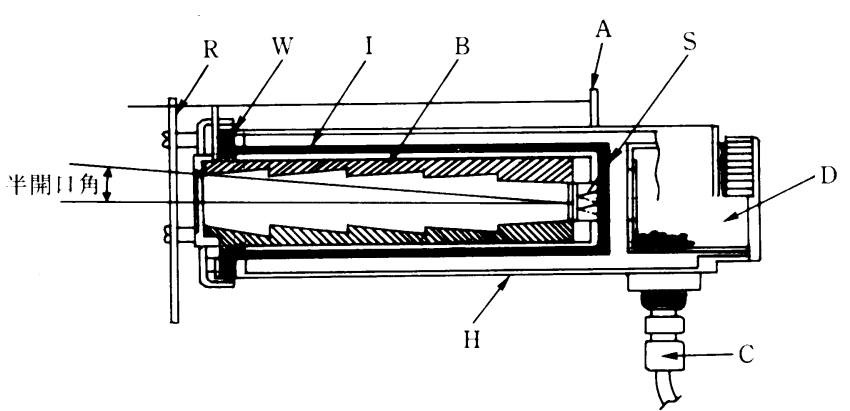

$\mathrm{R}$ :反射板 $\mathrm{W}$ :ウインドウ $\mathrm{I}$ :断熱筒 $\mathrm{B}$ :バッフル $\mathrm{A}$ :照準器

$\mathrm{S}$ :センサ $\mathrm{H}$ :外装 $\mathrm{D}$ :乾燥剤 $\mathrm{C}:$ :コクタ

\section{目 2 直達日射計受光器の粺造}

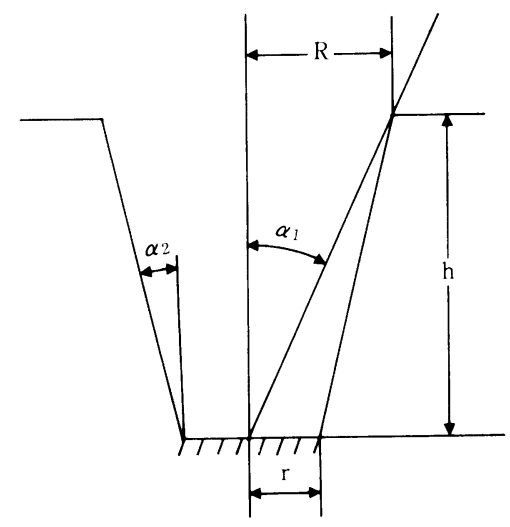

$\alpha_{1}$ :半開川角 $\alpha_{2}$ :傾斜角 $\mathrm{r}$ : センサ半径

$\mathrm{R}$ :開山半径 $\mathrm{h}$ :筒 長

図 3 直達日射計の開口部

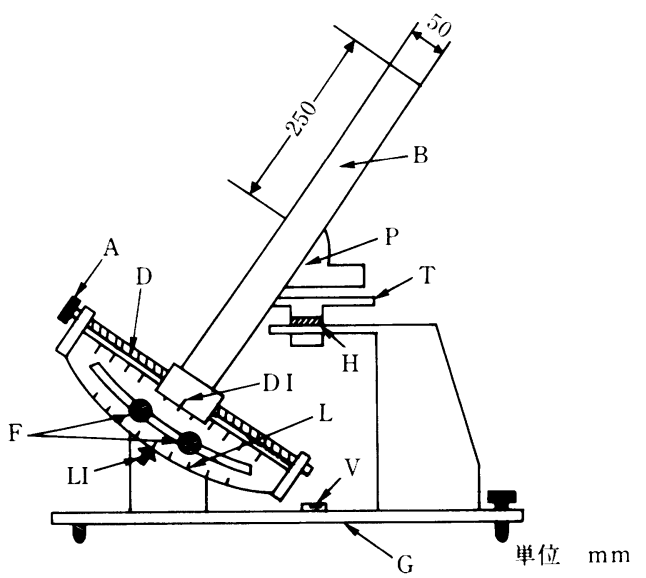

$\mathrm{B}$ ：遮蔽バンド $\mathrm{P}$ ：日射計(照度計) $\mathrm{T}$ ：固定台 $\mathrm{H}$ :高さ 位置調節 D : 赤緯目盛 DI:赤緯指標 L : 緯度目盛 LI:緯度指標 $\mathrm{A}$ : 赤緯調節 $\mathrm{V}$ :水隻器 $\mathrm{G}$ :基 板 $\mathrm{F}$ : 緯度固定ボルト

图 4 遮蔽バンドの槽造（拡散光測定用）

点の変動を最少に押える工夫であり，照度計のドームの役 割の上にも5一つの機能を持たせたてとが日射計測の場合 のドームの大きな特長である.

日射計測の場合拡散面としては黒化された受光面がその
役割をはたす，図 2 B に示されている全天日射計の構造で は面積の異る 2 枚の受光面の温度差が日射量に比例して取 出せる構造となっている. 全天日射計では日射に比例した 出力を取出す種々な構造が奏現されているが，ての方式が 現在では一番進んだものである ${ }^{1)}$. 図 $1(\mathrm{~A}),(\mathrm{B})$ には示され ていないが，いずれの場合もガラスドーム内の結露を防ぐ ために乾燥剤が容器に収められている.

次に直射照度と直達放射照度（直達日射量）を計測する 計測器の受光器 (受感器) の部分の構造を図 2 亿示す: 自 然光や風による急激な表面部分の温度変化をセンサになる ベく影響を及ぼさないよ5に率熱筒の中にセンサは収納さ れている，直射照度と直達放射照度（直達日射量）を計測 する場合重要なととはその開口部の角度関係である：太陽 の光球を見込む視直径は $32^{\prime}$ であるが，連続測定には受光 器部を常に太陽に正対させるための赤道儀に塔載しなけれ ばならず，乙の追従精度が問題となるため通常半開口角と して $2.5^{\circ} \sim 4.0^{\circ}$ の範网で受光器は設計されている. この 角度関係の規定を図 3 亿示す ${ }^{2}$. 即ち角度関係は半開口角 と傾斜角の 2 つ角度により規定されている．この開口角 の大きさは太陽の周辺光もある程度含んで計測するてとを 意味し, 大気条件（混濁係数，太陽高度）によって周辺光 量が変化するので計測誤差の要因となる，その大きさは太 陽高度が $20^{\circ}$ で，500 nm における混濁係数が 0.4 で都市 型の浮遊粒子の粒径分布が与えられる場合では值達日射量 の約 $4 \%$ 亿及ぶ3． また，開口角よりも大きい角度より 入射する周辺光を含む拡散光の混入を防ぐため 4 段のバッ フルが備えられている.

次に，拡散光 (天空照度, 散乱放射量) の計測には $2 \pi \mathrm{Sr}$ よりの入射光を測定する前記の照度計や全天日射計を $\dot{中}$ ヘウバンドにより直射光からしゃへくすることにより行わ れる. この構造の大略を図 4 に示す. しゃへヴバンドは太 陽の赤緯の率化により 1 ２ 日に 1 回バンドの高さを調整 する必要がある，また，㐫へヴバンドは直射光以外の拡 散光もしゃへんすることになるのでての補正が必要とな る.との補正法はバンドの直径とその幅等より下記の式が 今回の昼光測定年の計測には採用された ${ }^{2) 4)}$.

$$
f=\frac{2 b}{\pi r} \cos ^{3} \delta \sin h
$$

ここで， $f$ はバンドでさえぎられている拡散光の全体の 拡散光に対する割合を示している。 また $\delta$ は赤緯を，bは バンドの幅, $r$ はバンドの直径， $h$ は太陽高度をそれぞれ 示す. しかしとの式は拡散光の角度分布が均一であること を仮定しているので完全なものではない，そてで，直射光 のみをさえぎるディスクを赤道儀に装備して計測する方法 もあるが，装置が高価になること，メンテナンスが多少不 便になる等の理由により連続計測にはあまり使われていな 々. この補正の量は中緯度地方での計測で冬期には $5 \%$, 夏期には太陽高度が高いので $15 \%$ 位のオーダとなる。

今回の国際昼光測定年の計測には輝度の計測も含まれて

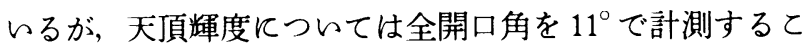


とになっておりセンサの構造は開口角を除き図 2 と同じで ある。また，日照時間の計測は専用計測器によるが，日照 時間の定義は直射日射量が $120 \mathrm{~W} / \mathrm{m}^{2}$ 以上の時間帯となっ ているので゙，直射日射量の計測值を加工することにより 得るとともできる. 専用の機器についての詳細については 本稿の範井を越えると思われるので他にゆずりたい5).

\section{3. 性能とその表示方法}

照度, 輝度と日射計の出力は多くの場合, 電圧出力 $V$ と して取出され，常数 $K$ を介して測定量 $E$ 亿変換される. 即 ち

$$
E=V / K
$$

と表現できる。とのKの価は多くの計測器，特に照度，輝 度計では計器の中で電気的に処理され, 測定量が各々の単 位で直接表示または記録される，日射量の高精度の測定の 場合には，日射量一の換算は事後処理されることが多い. 本項で取上げるととは 2 項の測定条件が与えられた時， $K$ はもはや常数でなく変数であるといらととである. 即ち $K$ は,

$$
K=\mathrm{f}(\mathrm{S} . \text { D. } \mathrm{T} \cdots \cdots .)
$$

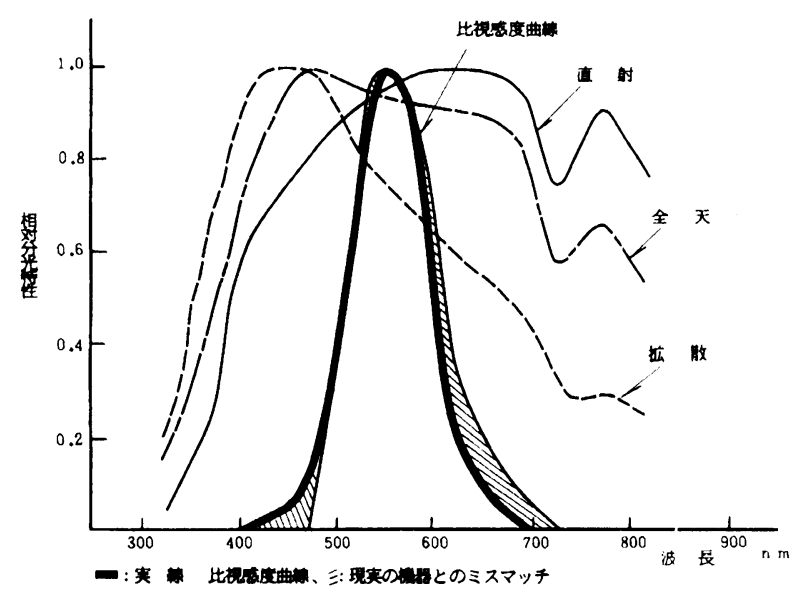

\begin{tabular}{|c|c|c|c|c|c|}
\hline 表 示 & 程 & 別 & 大気経程 & 混濁係数 $(0.5)$ & 可降水分 \\
\hline 点 & 㹡 & 散 & 1.5 & 0.27 & $5.0 \mathrm{~cm}$ \\
\hline 一点破線 & 全 & 天 & 1.0 & 0.10 & $5.0 \mathrm{~cm}$ \\
\hline 二点破線 & 直 & 射 & 4. 0 & 0.50 & $5.0 \mathrm{~cm}$ \\
\hline
\end{tabular}

— : 実線 比視感度曲線, $\mathbb{I} /$ : 現実の機器とのミスマッチ

目 5 分光分布と分光特性

\begin{tabular}{|c|c|c|c|c|c|c|}
\hline \multirow{2}{*}{ No. } & \multirow{2}{*}{ 種 } & \multirow{2}{*}{ 類 } & 大 気 & 条 件 & \multirow{2}{*}{$\mathrm{R}$} & \multirow{2}{*}{$\mathrm{R} / \mathrm{R}_{2}$} \\
\hline & & & 大気路程 & 混濁係数 & & \\
\hline 1 & 值 & 射 & 4 & 0.50 & 0.851 & 0.952 \\
\hline 2 & 全 & 天 & 1.0 & 0.10 & 0.894 & 1. 000 \\
\hline 3 & 全 & 天 & 4. 0 & 0.50 & 0.889 & 0.994 \\
\hline 4 & 拡 青 & 始乱） & 1.5 & 0.27 & 0.915 & 1.023 \\
\hline 5 & 雲 & 天 & $\sim$ & $\sim$ & 0.873 & 0.982 \\
\hline
\end{tabular}

表1 各種大気条件による分光特性インデックス
の如く各種要素の関数として与えられることを示す. S. D. T はその要素の例として分光特性, 角度特性, 温度 特性を各々示している。乙れ等の特性は性能として表現さ れる. 以下, 自然光計測上特に重要な特性について説明し たい.

\section{1 分光感度特性}

自然光を照度，輝度として計測する場合，先にも述べた 通り自然光の分光分布は時間と共に, 又大気条件により大 きく変る. この変化の中でセンサーの相対分光感度 $S_{\lambda}$ と 標準比視感度曲線 $V_{\lambda}$ のミスマッチに起因して，(4)式に与 えられるインデックス Rがどのよらに変るかを評価すれば よい. 即ち

$$
R=\int_{400}^{700} I_{\lambda} \cdot V_{\lambda} d_{\lambda} / \int_{400}^{700} I_{\lambda} S_{\lambda} d_{\lambda}
$$

として示される．とこで $I_{\lambda} は$ 自然光の相対分光分布であ る. $I_{\lambda}$ の変化の程度は次のよらに考えるととができる. すなわち，最も短波長側にずれた場合として快晴時の拡散 光を想定し，一方最も長波長側にずれた場合は太陽高度が 低く（例えば大気路程 4.0 , 太陽高度 $14.5^{\circ}$ ） かつ混濁係 数が大をい場合（例えば $0.5 \mu \mathrm{m}$ において $0.5 ）$ 直射光を 想定すればよん．また，中間的には曇天時を想定しほぼ分 光分布が均一な場合を取上げる. 図 5 に各々の場合におけ る分光分布 $I_{\lambda}$ を日射モデルにより計算した結果を示す ${ }^{6)}$. この結果を利用し, 式 4 亿よるインデックス $R$ の計算結果 を表 1 亿示す. 七ンサの相対分光感度としては今回の国際 昼光測定年の観測に使用された照度計の相対分光感度を用 レた.との結果によると最大誤差として約 $7 \%$ 手想され る.そこで誤差を少なくする工夫として照度，輝度計を全 天，直射用と拡散用に別々の重みをつけたデータ処理をす るととが考えられる．乙の場合の誤差は約 $4 \%$ に減る.

各種の規格によると照度, 輝度計の相対分光感度と標準 A 光源を使った場合のインデックスを与えている たインデックスの内容も多少異なる．こてでは温度 2856 $\mathrm{K}$ の黒体に相当する $\mathrm{A}$ 光源でなく, 自然光そのものの分 布を与え，実用に直接結びつけた。 また，前記規格の中に は紫外線, 赤外域の分光感度特性も規定しているが, 自然 光を対象として考える時, 通常の照度, 輝度計では問題に なるよらな誤差とはならない。

次に全天日射計についても基本的には同じことがいえる が，波長 0.3〜3.0 $0 \mathrm{~m}$ 間の分光特性に関係するガラスド 一ムの透過率と黒色塗料の吸収率のみで分光特性は決まる ので，大きな誤差とはならず約 $0.2 \%$ オーダである. WMO と ISO の全天日射計についての分光感度特性の規 定も（透過率）×(吸収率）が波長範囲 $0.3 \sim 3.0 \mu \mathrm{m}$ 間で $\pm 5.0 \%$ 偏差を 1 級の全天日射計に規定しているに過ぎ ない229). 今後の課題として，センサに斜入射した光に対 する分光感度特性を実測し, さらに実用的なデータとする ことが残されている. 


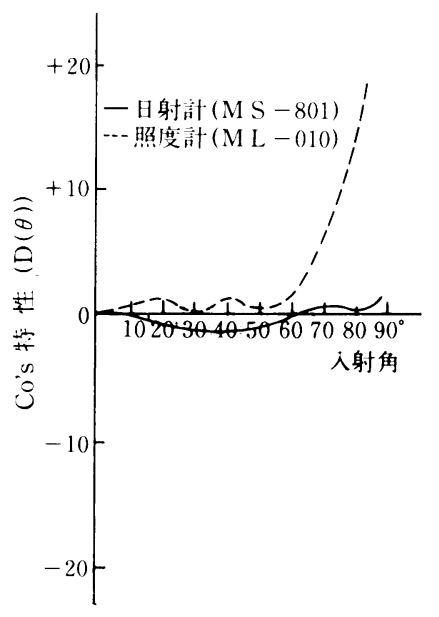

图 $6 \cos$ 特性

\section{$3.2 \cos$ 特性}

前記分光特性と共に重要視される特性でありながらての 評価は大変むつかしい. $\cos$ 特性は通常下記の式で示され る.

$$
D_{(\theta)}=\left(\frac{V_{\theta}}{V_{(0)} \cos \theta}-1\right) \cdot 100 \%
$$

ここで， $D_{(\theta)}$ は $\cos$ 特性， $V_{(0)}, V_{(\theta)}$ はそれぞれ入射角 度 $0^{\circ}$ と $\theta^{\circ}$ におけるセンサの出力である. 式 5 より容易に わかることは入射角度が大きくなった時の $\mathrm{V}_{(\theta)}$ は非常に 小さい価となり必然的に誤差の百分率が大きくなる.よっ て結果として与えられる $\cos$ 特性 $D_{(\theta)}$ も大をな誤差とな る. また, 実際的にもこの特性が問題となるのは入射角度 が大きくなった時である. 一方, 自然光の空間分布（角度 分布）は晴天時には 3.1 亿述べた同じ取扱いで日射計算モ デルで与えられるが，雲のある場合は実測に頼る以外に方 法がない. 種々な天空状態における分布の実測值の統計的 な処理により分類できるかもしれないが寽来に残された問 題である．乙こでは輝度の角度分布 $I_{(\theta)}$ が与えられたとし た場合の $\cos$ 特性にもとづくインデックス $R_{(\theta)}$ を示す.

$$
R_{(\theta)}=\int_{0}^{\frac{\pi}{2}} I_{\theta}\left(1+D_{(\theta)}\right) \sin 2 \theta d \theta / \int_{0}^{\frac{\pi}{2}} I_{\theta} \sin 2 \theta d \theta
$$

ここで， $I_{(\theta)}$ は入射角 $\theta$ において全方位角で平均した輝 度を示す.

図 6 亿照度計と全天日射計の $\cos$ 特性を参考までに示 す. CIEの規格ではセンサとしてのとの特性の表現法とし て下記を採用している ${ }^{8)}$.

$$
f_{2}=\int_{0}^{85^{\circ}} D_{(\theta)} \sin 2 \theta d \theta
$$

こてで $f_{2}$ は, $\cos$ 特性にもとづく, 誤差の程度を一つの インデックスで示したものである，ての方法で前記照度 計, 全天日射計について与えられる $f_{2}$ の価はそれぞれ 1.9 \%と $0.42 \%$ とな.

また，ここまでの説明では方位角の特性については触れ ていないが，当然てれも問題となる. 自然光計測の場合先
にも述べたごとく，角度分布について現在情㪕がとぼしい のでこれ以上の検討は今後に残されている.

一方，全天日射計についての ISOの規格 ${ }^{9)} に よ る \cos$ 特 性の表現方法は入射角 $0^{\circ}$ の方向から $1000 \mathrm{~W} / \mathrm{m}^{2}$ のビーム を与六た時，あらゆる人射角（会む方位角）に対しての誤 差が 1 級の全天日射計で最大 $\pm 20 \mathrm{~W} / \mathrm{m}^{2}$ を許容している. この表示法は大変合理的でューザはこの数字より日射量が いくらであっても最大 $\pm 20 \mathrm{~W} / \mathrm{m}^{2}$ の人射角（含む力位角） による䛊差を子測することができる。ちなみに，これを前 記 $\cos$ 特性 $D_{(\theta)}$ を入射角 $80^{\circ}$ で換算してみると, $D_{(\infty)}= \pm 11 \%$ とる。また，参考までにJIS 規格では， AA 級の照度計（最高）で， $D_{(\infty)}= \pm 25 \%$ を許容している がこの規格では自然光の連続観測には不適ではないかと思 われる．以上の説明の通り，別々の発展の歴史をたどっ た, 照度計と全天日射計の $\cos$ 特性のとらえ方と表現方法 の違いについてご理解いただけるものと思う。

\section{3 温度特性}

2 項で述べたごとく, 通常の屋外観測では $50^{\circ} \mathrm{C}$ の温度 幅の中で使用されると考え，この間でセンサの出力がどれ 位変るかで表現すればよい，また，温度係数として与える こともできる．乙の特性は気温が測定されておればての係 数によって出力を補正すれば測定の精度は非常に上る。通 常使用されている照度計，全天日射計の温度係数はそれぞ れ $0.15 \% /{ }^{\circ} \mathrm{C}$ と $0.06 \% /{ }^{\circ} \mathrm{C}$ の程度である.

\section{4 その他の特性}

次に，取上げる特性は零点の安定性の問題であるが，照 度，輝度計については問題はない．全天日射計については 2 項でも説明した通り，風や赤外放射の影響により少なか らず零点が移動する．今 IEA*の日射計測部会で準備され ているユーザズマニュアルでは 1 週間程夜間（日射がない 時）の全天日射計の出力の平均値を測定值よりさし引く手 法が提案されている．ただ今回の国際㡺光測定年に使用さ れた全天日射計ではこの変動が極めて少なく，2.5 W/m $\left(1000 \mathrm{~W} / \mathrm{m}^{2}\right.$ に対し $\left.0.25 \%\right)$ 程度であるので，補正の必 要はない。

次に感度常数の経年変化を取上げると全天日射計では最 大で年に約 $1 \%$ 位である，照度，輝度計については使用す る光電素子とフィルタの光学的特性により判断すると経年 変化は殆んど考えられないが，実測の結果を待たねばなら ない. 直線性については光電素子の性質上 3 析までは保証 できるので，他の誤差に比較し非常に少なく $0.1 \%$ オー ダである。また全天日射計については $0.2 \%$ を越えること はない.さらに全天日射計を垂直面にとりつけて使用する 場合，乙の傾斜特性が問題となるが，0.15\%以下である. 一方照度計, 輝度計ではこの問題はない。これらの取上げ た特性の他に偏光に対する問題, 応答速度の問題等がある

\footnotetext{
* International Enargy Agency
} 


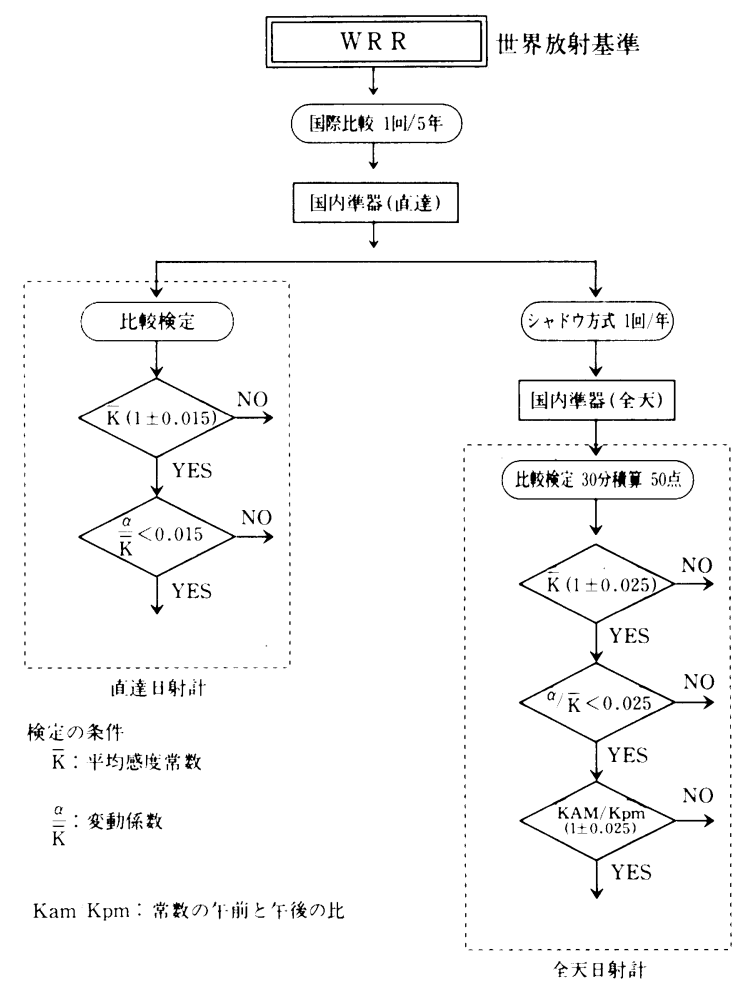

图 7 日射計の校正流れ図

がこの稿では割愛させていただく。

以上がセンサについての特性であるが, 次にセンサの出 力を処理するデータ集録装置について一番大切なととは分 解能である. 分解能としては $1 \mu \mathrm{V}$ が望ましく, その他の 不確さを合計しても $5 \mu \mathrm{V}$ 以下であるてとが望ましい.

また，データのサンプリング速度は測定の目的に依存す るが，一時間の平均值を得るには 1 分でとのサンプリング で十分である。

\section{4. 校正}

自然光を対象とする時, 計測機器の特性と共に校正の問 題はさけて通るてとはでをない，全天日射計については図 7 の流れに従って気象庁で行れている ${ }^{1)}$. ての方法は WRR（世界放射基準）を基準としている WMO でその価が維持され， 5 年に 1 回各国の準器を持ち 寄り比較観測により準器の価の見直しが行れる.しかし, てれは直達日射量についてであり, 全天日射量は各種の方 法により直達日射量より移し変えられる ${ }^{122)}$. この間で生 ずる誤差もかなりあり，現在は $\pm 2.5 \%$ 一つのめどとし て考えることができる，ての詋差については現在非常に議 論があり近い将来改善されるであろら.

次飞照度の目盛づけの方法はすべての規格において標準 A 光源を利用して行らてとになっているが，てれをそのま ま自然光の計測に適用するのは問題があると考えられる. 何故なら，校正用の前出の $\mathrm{A}$ 標準光源と自然光の分光分
布と角度分布が異るからである，校正するセンサの分光感 度特性, したがって，A標準光源飞正対させて校正した值 をそのまま自然光に適用することは極めて危険である。と いって，現在照度については自然光による校正方法が確立 していないので，JIS AA 級の照度計を使用して以下の方 法で校正を行った。 JIS AA 級の照度計と, 被校正照度計 を晴天時太陽に正対させ，両者を各々の形状に対応した同 じ開口角のデイクで直射光をしゃへくした時としない時の 出力の差, すなわち準器 AA 級で与えられる直射照度を 基準にして校正を行った．この校正精度については，今後 の検討課題である．将来は全天日射計で取人れられている よらな方法を検討する必要がある。

\section{5. 結語}

以上昼光および日射の計測機器について, 構造, 性能, 校正方法の概略について解説したが，全天輝度分布の計 測，日照時間等の計測は割愛させていただいた。 また，今 後検討すべを問題点として角度特性の検討と校正法の問題 等がある、日進月歩のこの分野では今後てれらの問題は十 分解明されて行くものと思 5. 本稿隹対する読者の批判, 意見がこの分野における技術の進歩につながるので，で批 判いただくと共に，今後共一層ので指導をお願い致した r.

\section{参考文献}

（1）柴田和雄, 内嶋善兵衛編：太陽エネルギーの分布と測定, 学会出版社 (1987) 37

(2) Guide to Meteorological Instruments and Methods of Observation, WMO No. 8. 5 th edition (1983) 97

(3) Solar Energy-Calibration of Field Phrheliometers by comparison to a Reference Pyrheliometer, ISO 9059 (1990)

(4) Drummond. A. J. : On the Measurement of Sky Radiation, Archive. Met. Geophys. Biakl. Serie B. (1956) 413

(5) Ikeda., H. Aoshima, T. and Miyake, Y.: Development of a Sunshine Duration meter, J. Met. Soc. JAPAN 64-6 (1986) 987

(6) Miyake, Y. Shimokawa, R. Nakanishi, Y. and Hamakawa, Y.: Global Radiation model and Angular Distribu tion of the Diffuse Irradiance. Solar cells 20 (1987) 127

(7) 照度計：JISC 1609-1983, JIS ハンドブック. 光学 日本 規格協会 (1985) 599

(8) Methods of Characterizing Illuminance and Luminance meters. Publ. CIE No. 69 (1987)

(9) Solar Energy-Specification and Classification of Instruments for Measuring Hemisphercal Solar and Direet Solar Radiation. ISO 9060 (1990)

(10) 三宅行美：日射計測の最近の動向, 太陽エネルギー, 14-5 (1988) 34

(受付1991年 5 月13日) 